\title{
ПРАВОВЕ РЕГУЛЮВАННЯ ЗАБЕЗПЕЧЕННЯ ЕКОЛОГІЧНОЇ БЕЗПЕКИ В УКРАЇНІ
}

\author{
Балюк Г. І., Ковальчук Т. Г.
}

\section{ВСТУП}

Постійність проявів екологічного ризику для життя і здоров'я людей, а також довкілля внаслідок небезпечних впливів техногенного та природного характерів зумовлюють необхідність активного пошуку дієвих заходів та підходів, спрямованих на попередження настання таких впливів, ліквідацію їх наслідків у разі виникнення небезпек, надзвичайних екологічних ситуацій. Чільне місце в системі таких заходів відводиться державно-правовому механізму, який передбачає цілу систему заходів і засобів, що спрямовані на гарантування екологічної безпеки, зокрема розвиток і вдосконалення законодавства в цій сфері.

Оскільки система правовідносин, що формують екологічну безпеку, постійно змінюється, перебуває в динамічному русі, так само постійно змінюється і законодавство у сфері гарантування екологічної безпеки. Особливо це виявляється щодо напрацювання процедур, спрямованих на попередження виникнення небезпек. Не останню роль у цьому відіграють так звана «глобалізація», або «інтернаціоналізація» норм екологічної безпеки, запровадження обов'язкових вимог на загальносвітовому рівні, регіональне співробітництво, зокрема тенденція гармонізації окремих положень національного законодавства 3 європейськими нормами безпеки, урахування позитивного досвіду правового регулювання, накопиченого міжнародною спільнотою. Подальшого розвитку набуває вдосконалення екологічного законодавства - спрямування його насамперед на захист суб'єктивного права громадян на безпечне для життя і здоров'я довкілля.

Правові норми щодо гарантування екологічної безпеки містяться сьогодні в більшості законодавчих і підзаконних нормативно-правових актів, тим самим справляючи комплексний, міжгалузевий вплив на регламентацію правовідносин у різних сферах діяльності, особливо щодо здійснення екологічно небезпечної діяльності. Наявність розвиненої системи джерел права у сфері екологічної безпеки - суттєва умова забезпечення здійснення права громадян на екологічно безпечне для життя і здоров'я довкілля. 


\section{1. Стан сучасного законодавства України у сфері гарантування екологічної безпеки}

Положення щодо гарантування екологічної безпеки містяться

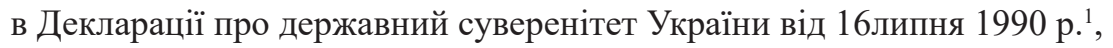
у якій виділено окремий розділ «Екологічна безпека», у Конституції України ${ }^{2}$, Основних напрямах державної політики України в галузі охорони довкілля, використання природних ресурсів та забезпечення екологічної безпеки (1998р.) $)^{3}$, Законі «Про національну безпеку України» від 21 червня 2018 р. ${ }^{4}$ та інших нормативно-правових актах. Конституція України не лише проголосила право громадян на безпечне для життя та здоров'я довкілля, а й передбачила систему гарантій цього права.

Особливу увагу екологічній безпеці приділено в Законі України «Про охорону навколишнього природного середовища» від 25 червня 1991 р.5 (р. ХІ, ст.ст. 50-59). Норми цього розділу закріплюють екологічні вимоги щодо окремих видів діяльності: інвестиційної, господарської та у процесі розміщення і розвитку населених пунктів (містобудівної) (ст.ст. 51, 59); транспортних засобів (ст. 56); щодо проведення наукових досліджень, упровадження відкриттів, винаходів, застосування нової техніки, імпортного устаткування, технологій і систем (ст. 57) та щодо військових оборонних об'єктів і військової діяльності (ст. 58), а також вимоги щодо охорони довкілля від неконтрольованого та шкідливого біологічного впливу (ст. 53); від акустичного, електромагнітного, іонізуючого та іншого шкідливого впливу фізичних факторів і радіоактивного забруднення (ст. 54); від забруднення виробничими, побутовими, іншими відходами (ст. 55); у процесі застосування засобів захисту рослин, мінеральних добрив, токсичних, хімічних речовин та інших препаратів (ст. 52).

\footnotetext{
1 Декларація про державний суверенітет України від 16 липня 1990 р. Відомості Верховної Ради Украӥнської Радянської Соціалістичної Республіки. 1990. № 31. Ст. 429.

2 Конституція України від 28 червня 1996 р. Відомості Верховної Ради Украйни. 1996. № 30. Ст. 141.

3 Про основні напрями державної політики України в галузі охорони довкілля, використання природних ресурсів та забезпечення екологічної безпеки : постанова Верховної Ради України від 5 березня 1998 р. № 188/98-ВР. Відомості Верховної Ради України. 1998. № 38. Ст. 248.

4 Про національну безпеку України : Закон України від 21 червня 2018. Відомості Bepховної Ради Украӥни. 2018. № 31. Ст. 241.

5 Про охорону навколишнього природного середовища : Закон України від 25 червня 1991 р. Відомості Верховної Ради Украӥни. 1991. № 41. Ст. 546.
} 
Діяльність, яка перешкоджає здійсненню права громадян на безпечне для життя і здоров'я довкілля (ст. 50 Конституції України), підлягає припиненню в порядку, установленому законодавством України, зокрема в судовому порядку. Підставою для припинення діяльності підприємства $є$ систематичне порушення екологічних нормативів (зокрема, нормативів екологічної безпеки) й екологічних стандартів, що не можуть бути усунені з технічних, економічних та інших причин.

Закон України «Про охорону навколишнього природного середовища» закріплює повноваження органів держави у сфері екологічної безпеки. Зокрема, на Верховну Раду України покладається встановлення правового режиму зон надзвичайної екологічної ситуації, статусу потерпілих громадян, визначення повноважень рад, порядку організації та діяльності органів управління в галузі гарантування екологічної безпеки та прийняття до свого розгляду інших питань у цій сфері.

Норми, що регулюють питання екологічної безпеки, містяться не лише в законодавчих актах власне екологічного спрямування, а й актах іншого законодавства, спрямованого на регулювання різних видів діяльності. Це, зокрема, нормативно-правові приписи, які:

- визначають статус органів місцевого самоврядування та їхні повноваження в галузі гарантування екологічної безпеки, передбачені Законом України «Про місцеве самоврядування» від 21 травня 1997 р.; - закріплюють статус органів центральної та місцевої виконавчої влади, спеціалізованих структур у галузі екологічної, зокрема техногенно-екологічної, безпеки: Закон України «Про Раду національної безпеки і оборони України» від 5 березня 1998 р., Положення про Державну службу України з надзвичайних ситуацій, затверджене постановою Кабінету Міністрів України від 16 грудня 2015 р., та інші;

- спрямовані на захист життя та здоров'я людей і довкілля від надзвичайних ситуацій техногенного і природного характеру, які містяться, зокрема, у законах України «Про об’єкти підвищеної небезпеки» від 18 січня 2001 р., «Про забезпечення санітарного і епідемічного благополуччя населення» від 24 лютого 1994 р.;

- регламентують забезпечення екологічних вимог, зокрема вимог екологічної безпеки, у надзвичайних ситуаціях: закони України «Про правовий режим надзвичайного стану» від 16 березня 2000 р., «Про зону надзвичайної екологічної ситуації» від 13 липня 2000 р. тощо;

- зобов'язують дотримуватися вимог екологічної безпеки в межах територій і зон, на яких запроваджено режим надзвичайних 
екологічних ситуацій: Закон України «Про правовий режим території, що зазнала радіоактивного забруднення внаслідок Чорнобильської катастрофи» від 27 лютого 1991 р.;

- спрямовані на забезпечення ядерної і радіаційної безпеки (як складників і передумови екологічної безпеки) у процесі використання ядерної енергії, видобування та переробки уранових руд, поводження 3 радіоактивними матеріалами і відходами та радіаційний захист населення: закони України «Про використання ядерної енергії та радіаційну безпеку» від 8 лютого 1995 р., «Про поводження з радіоактивними відходами» від 30 червня 1995 р., «Про дозвільну діяльність у сфері використання ядерної енергії» від 11 січня 2000 р., «Про фізичний захист ядерних установок, ядерних матеріалів, радіоактивних відходів, інших джерел іонізуючого випромінювання» від 19 жовтня 2000 р., «Про захист людини від впливу іонізуючого випромінювання» від 14 січня 1998 р.;

- містять вимоги щодо гарантування екологічної безпеки у процесі стандартизації і сертифікації продукції, товарів тощо: Закон України «Про стандартизацію» від 5 червня 2014 р.;

- закріплюють вимоги екологічної безпеки під час здійснення інвестиційної, інноваційної, містобудівної та іншої господарської діяльності: закони України «Про інвестиційну діяльність» від 18 вересня 1991 р., «Про ринок електричної енергії» від 13 квітня 2017 р. та інші;

- містять комплекс спеціальних вимог щодо гарантування екологічної безпеки в разі здійснення діяльності в аграрному секторі економіки: закони України «Про сільськогосподарську кооперацію» від 17 липня 1997 р., «Про особисте селянське господарство» від 15 травня 2003 р., «Про фермерське господарство» від 19 червня 2003 р.;

- встановлюють вимоги екологічної безпеки у процесі здійснення деяких специфічних видів діяльності, що можуть негативно впливати на стан екологічної ситуації: Закон України «Про космічну діяльність» від 15 листопада 1996 р.;

- визначають вимоги екологічної безпеки у процесі використання хімічних та інших токсичних, шкідливих і небезпечних речовин, їх сполук, продуктів біотехнологій, інших біологічних агентів, а також мінеральних добрив, зокрема пестицидів і агрохімікатів: закони України «Про пестициди і агрохімікати» від 2 березня 1995 р., «Про державну систему біобезпеки при створенні, випробуванні, транспортуванні та використанні генетично модифікованих організмів» від 31 травня 2007 р. та інші; 
- спрямовані на регламентування екологічної безпеки у процесі реалізації продукції, товарів та захисту прав споживачів: закони України «Про захист прав споживачів» від 12 травня 1991 р., «Про основні принципи та вимоги до безпечності та якості харчових продуктів», у редакції від 22 липня 2014 р., та інші;

- закріплюють нормативно-правові вимоги щодо гарантування екологічної безпеки у сфері територіальної та цивільної оборони: Кодекс цивільного захисту України від 2 жовтня 2012 р., Закон України «Про оборону України» від 6 грудня 1991 р.;

- визначають склад правопорушень у цій сфері та підстави і порядок притягнення винних осіб за їх учинення до дисциплінарної, адміністративної, кримінальної, цивільної, еколого-правової відповідальності. Такими є, зокрема, норми, що містяться в Кодексі законів про працю України від 10 грудня 1971 р., Кодексі України про адміністративні правопорушення від 7 грудня 1984 р., Кримінальному кодексі України від 5 квітня 2001 р., Цивільному кодексі України від 16 січня 2003 р., Земельному кодексі України від 25 жовтня 2001 р., Кодексі України про надра від 27 липня 1994 р. тощо;

- регламентують діяльність правоохоронних органів у галузі гарантування екологічної безпеки: Закон України «Про прокуратуру» від 14 жовтня 2014 р.

Зазначимо, що законодавство у сфері гарантування екологічної безпеки в Україні розвивається динамічно і передбачає сукупність важелів як регламентуючого, так і забезпечувального спрямування.

Однак, на нашу думку, варто враховувати реальний стан чинного вітчизняного екологічного законодавства, якому притаманні такі недоліки:

- надмірна декларативність законів, відсутність чітко відпрацьованого механізму дії їх приписів, унаслідок чого такі закони «обростають» численними підзаконними актами, які нерідко інтерпретують положення законів на догоду відомчим інтересам, ще гірше - на догоду однієї особи (згадаймо хоча б історію приватизації Межигір'я) чи окремих «кланів» і вихолощують їхню суть;

- дублювання однакових норм у різних законах та інших нормативних актах;

- невиправдана поспішність у підготовці й ухваленні низки законів та інших нормативних актів;

- слабка соціологічна забезпеченість підготовки проєктів еколого-правових нормативних актів, відсутність аналізу соціально-економічних та інших наслідків ухвалення рішень; 
- відсутність комплексного підходу до регулювання екологічних суспільних відносин тощо.

Приєднуємося до думки Ю. Шемшученка про те, що «у праві немає або практично немає місця для експериментів - за кожним рішенням, спрямованим на створення і реалізацію права, стоять долі людей і інтереси громадян, суспільства, держави. Тому право повинно бути максимально досконалим і системним» ${ }^{6}$.

На наш погляд, наведений висновок повною мірою поширюється на екологічне законодавство у сфері гарантування екологічної безпеки, яке потребує подальшого розвитку.

Як передумови подальшого розвитку екологічного законодавства України можна вибрати різні за масштабами, сферою прояву, значенням, стилем прояву й ефективністю дії чинники соціального, економічного, політичного та правового життя. Зазначений відбір залежить багато в чому від цілі його проведення, частково - від підходу до поняття даної галузі законодавства, від визначення етапів його розвитку тощо.

I все ж, на нашу думку, безспірно, що вирішальними передумовами подальшого розвитку екологічного законодавства України на будьякому етапі незалежно від широкого чи вузького розуміння предмета правового регулювання є: 1) по-перше, соціально-екологічна криза (об’єктивний чинник); 2) по-друге, державна екологічна політика (суб'єктивний чинник).

Обидва зазначені чинники не меншою, якщо не більшою, мірою піддаються із плином часу (інколи дуже швидко) змінам під впливом інших явищ і процесів, найрізноманітніших за змістом. Розглянемо їх як певну даність у статиці, у показниках сьогоднішнього дня, залишивши за рамками в даному разі їхні динамічні характеристики.

Соціально-екологічна криза являє собою сукупність станів та змін навколишнього середовища, його компонентів і зв'язків між ними, що характеризується стабільним погіршенням і зростанням загроз людині та природі. Як бачимо, соціально-екологічна криза, як одна 3 передумов подальшого розвитку екологічного права, має дві складові частини: соціальну й екологічну. У даному разі на особливу увагу заслуговує саме екологічна складова частина зазначеного явища ${ }^{7}$.

\footnotetext{
6 Шемшученко Ю. Виміри порівняльного правознавства. Право України. 2013. №№ 3-4. C. $15-21$.

7 Надоша О. Теоретико-методологічний аналіз сталого розвитку в контексті сучасних дослідницьких підходів. Державне управління: удосконалення $і$ розвиток. 2011. № 10. C. 17.
} 
Екологічна криза - це якісна зміна параметрів природного середовища, його біологічних, фізичних, хімічних компонентів, що призводить до порушення умов життєдіяльності людини. За джерелами виникнення екологічні кризи поділяють на два типи: 1) спричинені природними процесами; 2) спричинені діяльністю людини. За масштабами соціально-екологічні кризи оцінюються як: глобальні, національні та регіональні ${ }^{8}$.

Проявами соціально-екологічної кризи, які спостерігаються на даному етапі в Україні, є: 1) виснаження природних ресурсів; 2) погіршення їхньої якості та зниження споживної цінності; 3) погіршення умов життєдіяльності людини, стану здоров'я людей під впливом чинників середовища перебування; виникнення загрози життю (живих організмів, зокрема людини $)^{9}$.

Дуже часто як прояви соціально-екологічної кризи визначають i чинники міжнародного масштабу, зокрема: руйнування озонового шару; зміну клімату; підвищення рівня вод Світового океану; зміни температурних характеристик в окремих районах Землі; засмічення космічного простору; зникнення тварин і рослин (тобто знищення біорозмаїття); погіршення якості атмосферного повітря внаслідок антропогенних навантажень у промислових районах та містах і транскордонного перенесення шкідливих речовин; зниження запасів прісної води в окремих регіонах земної кулі; масштабне споживання невідновлюваних природних ресурсів; перевиробництво відходів, поява нових захворювань людини, тварин і рослин, їх генетичні зміни тощо.

Зазначимо, що зміст названих чинників (якісні та кількісні їхні характеристики) в Україні певною мірою усвідомлені і враховуються під час ухвалення правотворчих і правореалізуючих рішень. Наприклад, для попередження змін клімату вживаються заходи щодо обмеження виробництва, використання та транспортування озоноруйнуючих речовин, здійснюються багаторічні програми щодо попередження вирубки лісів, розширення їх площ (наприклад, Програма «Посади дерево» тощо). 3 метою боротьби із забрудненням навколишнього середовища вводяться заборони на виробництво і використання шкідливих хімічних речовин і продукції, яка їх містить, установлюються особливі правила безпеки під час випуску

8 Данилов-Данильян В., Лосев К. Экологические вызовы и устойчивое развитие. Москва, 2000. С. 407.

9 Надоша О. Теоретико-методологічний аналіз сталого розвитку в контексті сучасних дослідницьких підходів. Державне управління: удосконалення і розвиток. 2011. № 10 . С. 17. 
генно-інженерно-модифікованих організмів у відкрите навколишнє середовище, стимулюється використання багаторазових пакувальних матеріалів, вводяться ліміти на розміщення відходів і квоти на викиди шкідливих речовин в атмосферу.

Однак, як свідчить реальний стан і аналіз практики реалізації екологічного законодавства в Україні, прояви екологічної кризи часом ігноруються або ж компетентними структурами докладається недостатньо зусиль, а інколи ця криза посилюється і непродуманою державною екологічною політикою та недосконалим законодавством, корумпованим екологічним управлінням і низкою інших чинників.

Як відомо, традиційно зі сплесками науково-технічного прогресу світ пов'язує свої надії на скоріше усунення складних соціальних суперечностей, якісні зміни в системі виробництва, поліпшення стану довкілля, підвищення рівня комфорту існування людини. Здавалося б, доводячи до досконалості техніку і технології, здобуваючи фундаментальні знання про власну природу, довкілля і всесвіт, людство має стати більш досконалим, благополучним і щасливішим. Проте разом із «приборканням» атома з'явилися проблеми ядерної та радіаційної безпеки та Чорнобилю. Поряд із прогресом медицини і фармації виникли такі феномени, як фармакологічне забруднення організму людини, з'явилися нові хвороби й інфекції. Разом із розшифруванням геному людини, проникненням у структуру ДНК живих організмів і створенням генетично модифікованих продуктів стало зростати побоювання, що довкілля поступово перетвориться на «постприроду» із новими істотами та штучно змодельованими процесами, а сама людина - на «постлюдину» зі штучними органами, технологічними імплантами, нелюдськими властивостями і непередбачуваними душевними процесами. Із цими твердженнями можна погоджуватись або ні. Зрештою, біотехнологія та генна інженерія - це лише знання й інструменти для досягнення тих чи інших суспільних цілей. Інша річ - система «стримувань і противаг», яка має тримати ці цілі у правовому і моральному полі. Саме в цьому сьогодні є складні проблеми.

Висловлена думка, що змінити ситуацію на краще в Україні можна лише за допомогою територій зі спеціальним екологічним «статусом» ${ }^{10}$. У такому разі, на нашу думку, усю територію України варто віднести до території зі спеціальним екологічним режимом. Однак, чи

\footnotetext{
10 Про рекомендації Парламентських слухань щодо дотримання вимог екологічного законодавства в Україні, напрямів реалізації і вдосконалення екологічної політики : постанова Верховної Ради України від 7 грудня 2000 p. URL: https://zakon.rada.gov.ua/laws/ show/2130-14.
} 
сприятиме ухвалення такого рішення вирішенню наявних проблем. Уважаємо, що ні.

На нашу думку, на рівні із Законом «Про охорону навколишнього природного середовища» в Україні необхідний закон про захист людини від шкідливого довкілля. Якщо навіть аналогів такого закону немає у світовій практиці, це зовсім не означає, що такий закон не потрібний. Насправді, що і кого тільки не захищають наші закони. Важко навіть перелічити. I формально всі вони захищають людину або вищі людські цінності. Але коли йдеться про конкретні явища, виявляється, що всі ці закони спрямовані радше на охорону окремих об' єктів довкілля або навколишнього природного середовища загалом.

Як уже було зазначено, сьогодні в Україні ухвалено чимало законів, які регулюють екологічні відносини, спрямовані на гарантування екологічної безпеки. Але зазвичай цих законов не дотримуються. На жаль, на сором нам, сьогодні вони менш дієві, ніж це було за радянських часів. Досвід, накопичений протягом останніх 25 років, на нашу думку, показує, що держава не завжди проявляє себе як «хороший власник і господар» у сфері природокористування, охорони довкілля та гарантування екологічної безпеки.

Зокрема, про правопорушення у сфері природокористування в Україні не чув хіба що глухий. На наш погляд, тільки жорсткі адміністративні приписи здатні сьогодні протистояти натиску егоїстично-кримінальних інтересів, які нині культивуються в суспільстві, зокрема у сфері природокористування та гарантування екологічної безпеки.

Принагідно зауважимо, що викладені положення не претендують на завершеність, беззаперечність і категоричність, авторам хотілося б, щоб вони послугували одним з імпульсів для подальших дискусій стосовно порушених проблем.

Зокрема, у Кримінальному кодексі (далі - КК) України є стаття 246 («Незаконна порубка лісу»), згідно з якою відповідальність настає лише за умови завдання істотної шкоди. Оцінювати ії до 2012 р. були уповноважені органи Державної екологічної інспекції, а після - це була прерогатива виключно державної екологічної експертизи, якою зазвичай на рівні областей займався лише один експерт.

До речі, якщо до 18 лютого 2016 р. перелік покарань у ст. 246 КК України мав продовження - із «конфіскацією незаконно добутого», то тепер цю норму вилучено. Тож, якщо керуватись нормою Закону, то у крадіїв неможливо вилучити автотранспорт і бензопили, з якими вони їздять «на роботу» до лісу, і навіть зрубану деревину. 
Зазначимо, що ці кардинальні зміни запроваджено ухваленим Верховною Радою України Законом «Про внесення змін до Кримінального та Кримінального процесуального кодексів України щодо виконання рекомендацій, що містяться у шостій доповіді Європейської комісії про стан виконання Україною Плану щодо лібералізації Європейським Союзом візового режиму для України, стосовно удосконалення процедури арешту майна та спеціальної конфіскації» ${ }^{11}$. Назва напрочуд довга, а суть коротка: крім заборони конфіскації незаконно зрубаної деревини, вилучили норму ст. 248 КК України («Незаконне полювання»), за якою підлягали конфіскації: «знаряддя і засоби полювання та все добуте».

Отже, як говорили давні римляни, запитаймо: кому ці нововведення вигідні? Відповідь на запитання, можливо, дозволить нам зрозуміти, що йдеться вже не про банальні крадіжки, а про добре організований кримінальний бізнес, який має «дах» на найвищому рівні.

Можливо, у Європі крадену деревину й автомобілі, на яких ii вивозять, справді не вилучають. Однак відомо, що штрафи там такі, що крадій сам продасть не лише знаряддя злочину, а й значну частину власного майна, щоб розрахуватись за завдану шкоду і не потрапити за грати. Після цього сам не вчинятиме «незаконні порубки лісу», а й іншим закаже.

Складна ситуація не тільки з лісами, а й на морі. Особливо на Азовському морі, яке фактично окуповане фінансово-промисловими компаніями. Унікальне Азовське море перетворюється на брудну калюжу і стає розсадником хвороб замість того, щоби там можна було оздоровлюватися. Адже морське узбережжя має відігравати свою роль рекреаційного спрямування. Те саме можна сказати і про Чорне море.

Саме тут хотілося б нагадати про те, що ще в 1975 р. відомий учений, наш Учитель, Мунтян В. у своєму дисертаційному дослідженні зазначав, що екологія стає теоретичним підгрунтям поведінки людини індустріального суспільства у природі, а право - основним її результатом $^{12}$. Однак, на жаль, поки що цього не склалося.

\footnotetext{
11 Про внесення змін до Кримінального та Кримінального процесуального кодексів України щодо виконання рекомендацій, що містяться у шостій доповіді Європейської комісії про стан виконання Україною Плану щодо лібералізації Свропейським Союзом візового режиму для України, стосовно удосконалення процедури арешту майна та спеціальної конфіскації : Закон України від 18 лютого 2016 р. Відомості Верховної Ради Украӥни. 2016. № 11. Ст. 127.

12 Мунтян В. Правовые проблемы рационального природопользования : автореф. дис. ... докт. юрид. наук. Киев, 1975. С. 7.
} 


\section{2. Проблеми систематизації законодавства України у сфері гарантування екологічної безпеки}

До того ж сьогодні гостро постало питання систематизації екологічного законодавства України.

По-перше, із природоресурсних кодифікаційних актів варто буде вилучити застарілі норми, дублюючі положення та колізії як усередині ресурсних підгалузей, так і на рівні галузевих еколого-правових взаємодій, заповнити прогалини у правовому регулюванні. Деякою мірою відповідні прогалини можуть бути усунені шляхом підвищення до законодавчого рівня окремих регулюючих положень підзаконних нормативно-правових актів.

По-друге, варто вжити заходів консолідуючого характеру: у кожній із природоресурсних підгалузей на даний час паралельно із відповідними кодексами діють значна кількість профільних законів. Так, земельні відносини, поряд із Земельним кодексом України, регулюються такими законами, як: «Про оцінку земель» від 11 грудня 2003 р., «Про охорону земель» від 19 червня 2003 р., «Про державний контроль за використанням та охороною земель» від 19 червня 2003 р., «Про землеустрій» від 22 травня 2003 р. тощо. Усі ці законодавчі акти треба об'єднати «під одним дахом» Земельного кодексу шляхом консолідації, водночас значно спростивши механізми правореалізації.

Аналогічна ситуація спостерігається у правовому регулюванні відносин щодо надр, де поряд із Кодексом України про надра від 27 липня 1994 р. діють також Гірничий закон України від 6 жовтня 1999 р, закони України «Про державну геологічну службу України» від 4 листопада 1999 р., «Про концесії» від 3 жовтня 2019 р., «Про угоди про розподіл продукції» від 14 вересня 1999 р. та інші. Зазначене свідчить про наявність підстав для проведення нового етапу кодифікації законодавства в цій сфері, потребу в новій редакції Кодексу України про надра з метою поліпшення кількісних і якісних характеристик відповідного законодавства.

Новий етап систематизаційних дій очікує й регулювання лісових та флористичних відносин.

Сьогодні вже ні для кого не є секретом, що суттєво відстає від потреб практики, що стрімко розвивається, регулювання водних відносин. Уже було кілька невдалих спроб переглянути Водний кодекс України, чинна редакція якого ухвалена 6 червня 1995 р., у процесі першої хвилі кодифікації природоресурсного законодавства України. Уважаємо, що нагальним на другому етапі систематизації 
екологічного законодавства має стати й упорядкування водного законодавства України шляхом розроблення нової редакції Водного кодексу України.

Історично, ще з радянських часів, склалося так, що базове природоресурсне регулювання формувалося в основному у формі кодексів. Лише фауністичне, флористичне й атмосфероохоронне законодавство мали на своїй вершині закони як головні джерела підгалузей. Уважаємо, що на другому етапі цього процесу має бути кодифіковане також законодавство про тваринний світ і атмосферне повітря шляхом ухвалення Кодексу України про тваринний світ та Кодексу України про атмосферне повітря. У другому з означених документів важливо повернутися до поєднання у процесі регулювання суто охоронного аспекту з регламентацією відносин щодо використання атмосферного повітря, що надасть даному нормативно-правовому акту ознак комплексності, яких йому нині бракує.

Систематизація екологічного законодавства повинна синхронізуватися з аналогічною спрямованістю законотворчих дій у деяких інших галузях законодавства, що мають органічні зв’язки з екологічною сферою та норми яких несуть виражене екологічне навантаження.

Це, зокрема, стосується ядерного законодавства. Воно регулює ядерні відносини, що склалися в Україні. Правова ситуація, що склалася в державі в цій сфері, характеризується значною розпорошеністю важливих положень ядерного права в сотнях нормативно-правових актів різної юридичної сили, різної сфери застосування, що спричинено значною кількістю суб'єктів нормотворчості. У результаті масив відповідних правових документів нині не становить єдиної, належно узгодженої системи. Актам, які створювались під егідою різних міністерств та інших центральних органів виконавчої влади, часто бракує комплексності в регулюванні, вони не позбавлені дублюючих і суперечливих положень, що створює колізії у процесі правозастосування. Деякі регулятивні положення, що містяться в підзаконних актах, потребують підвищення їхньої юридичної сили до законодавчого рівня. $€$ й такі положення ядерного законодавства, що мають тимчасовий характер, а отже, мають бути скасовані як такі, що втратили своє регулювальне значення.

Особливі вимоги ставить перед ядерним законодавством України і проголошений курс на європейську інтеграцію, однією з найважливіших умов якої є адаптація ядерного законодавства України до законодавства Європейського Союзу. Україна є учасницею всіх основних 
міжнародних договорів із питань розвитку ядерної енергетики, гарантування ядерної та радіаційної безпеки. Під егідою Організації Об'єднаних Націй (далі - ООН) та їі спеціалізованих установ, насамперед МАГАТЕ, крім того, напрацьовано значну кількість резолюцій, які, хоча й не $є$ актами обов' язкової сили, мають для держав та інших суб'єктів міжнародного права рекомендаційний характер, однак дають чіткі орієнтири щодо розвитку національних правових систем у певній сфері. На жаль, відповідні міжнародні документи не завжди належно враховані у правовій системі України під час регламентації ядерних відносин.

Уважаємо, що за цих обставин нашальним $є$ питання розроблення й ухвалення Ядерного кодексу України. Не торкаючись усіх аспектів опрацювання проєкту цього кодексу, зауважимо, що він має кореспондувати екологічному законодавству, зокрема майбутньому Екологічному кодексу, у питаннях гарантування екологічної безпеки під час розміщення, проєктування, реконструкції й експлуатації ядерних об'єктів, залучення громадськості до ухвалення рішень, що стосуються розвитку ядерної енергетики, здійснення державного контролю за додержанням вимог охорони довкілля, екологічної безпеки у процесі експлуатації АЕC, перевезенні, складуванні й утилізації ядерних відходів івідпрацьованого ядерного палива, інформування громадськості про стан ядерної та радіаційної безпеки тощо.

Синхронно з екологічною сферою варто також здійснювати систематизаційні дії в царині містобудівного законодавства. Останнє також уже пройшло шлях накопичення нормативно-правового матеріалу, який нині потребує систематизації. Водночас має бути забезпечено належне врахування вимог охорони навколишнього природного середовища в містобудівній діяльності, зокрема у плануванні територій, розвитку населених пунктів, спорудженні окремих об'єктів містобудування. Обнадійливі перспективи в цьому контексті пов'язувались із розробленням проєкту Містобудівного кодексу України, який було підготовлено й узято за основу Верховною Радою ще 30 червня 2010 р. (постанова Верховної Ради України № 2376-VI). На жаль, остаточній редакції цього законопроєкту не довелося побачити світ, насамперед у зв'язку з відсутністю належного опрацювання його концептуальних засад, реальної кодифікації правових норм, лише формальним поєднанням в одному акті положень різних законів. Натомість 13 січня 2011 р. ухвалено проєкт закону України № 2943-VI «Про регулювання містобудівної діяльності», нормами якого під виглядом удосконалення 
дозвільних і погоджувальних процедур у будівництві було практично знівельовано базові вимоги екологічного законодавства. Уважаємо за необхідне повернутися до розроблення проєкту Містобудівного кодексу України, а оптимальним часом розгортання відповідних робіт вважаємо період після ухвалення Екологічного кодексу України.

Пов'язаним систематизаційним процесом в екологічній сфері, на наш погляд, повинна стати й кодифікація енергетичного законодавства. Це законодавство в Україні натепер також являє собою розгалужену систему, значна частина норм якої прямо чи опосередковано взаємодіють 3 екологічним законодавством у регулюванні різних аспектів розвитку енергетики, зокрема щодо використання природних енергоресурсів, розміщення енергетичних об'єктів, будівництва ліній електропередач, їх експлуатації й охорони, енергозбереження, використання альтернативних джерел енергії тощо. Розроблення Енергетичного кодексу України є перспективним законотворчим кроком, який також має бути узгодженим із відповідними процесами в екологічному законодавстві.

Окремий законодавчий блок сьогодні в Україні становить законодавство про захист населення та територій від екологічно несприятливих наслідків надзвичайних ситуацій природного та техногенного походження. На даний час відповідне законодавство не впорядковане і позбавлене уніфікованих концептуальних засад. Уже була спроба кодифікувати законодавство 3 питань правового режиму територій, що постраждали від Чорнобильської катастрофи, та захисту населення, яке перебуває на радіоактивно забруднених територіях. Проєкт Чорнобильського кодексу України (реєстр. № 9254 від 20 березня 2006 р.) був внесений на розгляд Верховної Ради України IV скликання і лишився нерозглянутим. Серед причин, які спонукали до розроблення цього Кодексу, було названо: розпорошеність норм цього законодавства по різних законах та підзаконних нормативних актах, неприпустимі згідно із принципом верховенства права в державі (ст. 8 Конституції України) розбіжності між підзаконними й нормативними актами та законами, тобто брак комплексного підходу до врегулювання «чорнобильських» проблем, належного механізму контролю за неухильним виконанням відповідних норм і положень внутрішнього законодавства та міжнародних нормативно-правових актів, неналежне фінансування заходів, передбачених законами України «Про статус і соціальний захист громадян, які постраждали внаслідок Чорнобильської катастрофи» від 28 лютого 1991 р. та «Про правовий 
режим території, що зазнала радіоактивного забруднення внаслідок Чорнобильської катастрофи» від 27 лютого 1991 р.

Уважаємо, що зазначені проблеми мають бути вирішені у процесі кодифікаційних робіт щодо адміністративного, екологічного, фінансового та деяких інших галузей законодавства.

Крім сказаного, важливою складовою частиною регулювання екологічних відносин в Україні є екологізація інших галузей вітчизняного законодавства. Специфіка еколого-правових норм полягає в тому, що вони часто діють не безпосередньо, а через регулювання конкретної господарської чи іншої діяльності. Від того, наскільки органічно вплетені екологічні імперативи у тканину інших галузей законодавства, значною мірою залежить дієвість всієї системи еколого-правового регулювання. Важливо водночас усвідомлювати, що йдеться про норми, що не належать до галузі екологічного законодавства, а значить, і не входять до сфери його систематизації, але ці норми повинні бути враховані, простежені як такі, що забезпечують ефективність відповідних систематизаційних дій. Важливо, щоб відповідні норми не просто дублювали приписи екологічного законодавства, будучи механічно перенесеними до інших галузей, а відображали б специфіку тієї чи іншої галузі регулювання: господарської, цивільної, фінансової, адміністративної, трудової чи інших.

Важливо підкреслити, що становлення нової правової системи, на нашу думку, в Україні відбувається складно, суперечливо. Сьогодні робота з упорядкування законів і нормативно-правових актів екологічного спрямування є слабкою, недостатньо ефективною. Існують великі проблеми, пов'язані з відсутністю стратегічності в цьому сегменті, тобто його нестабільності.

Не вирішують проблеми в повному обсязі і численні законодавчі «латки» - зміни і доповнення до чинного законодавства. Фактично новації часто запроваджуються указами Президента України чи постановами Кабінету Міністрів України.

Такий стан речей викликає своєрідне відчуття безперспективності у проведенні кодифікаційних робіт у сфері, пов'язаній із регулюванням екологічних відносин, щодо гарантування екологічної безпеки.

Зазначена ситуація веде до таких негативних наслідків. По-перше, правозастосувачу стає важко орієнтуватися в законодавстві, яке швидко змінюється. Ми маємо деякі кодекси, які стали рікою, у яку неможливо ввійти двічі. Особливо у програшне становище потрапляють усі пересічні громадяни. Якщо професійний юрист, якість роботи якого прямо 
пропорційно залежить від підтримання в актуальному стані своїх знань про зміни чинного законодавства, користується однією з автоматизованих довідникових правових систем або виписує «Відомості Верховної Ради України», «Офіційний вісник», то інші громадяни не мають можливості обтяжувати свій бюджет такою статтею витрат. Коли громадянину необхідно ознайомитися із правовою нормою, він придбаває відповідний кодекс у найближчому книжковому магазині. У ситуації, що склалася, імовірність того, що куплений кодекс виявиться застарілим, досить висока.

Практично неможливо сьогодні придбати чинні кодекси в останній редакції, оскільки за той час, поки видання готується до друку, виходить 3 типографії і надходить на прилавки, у цей нормативний правовий акт вносяться нові зміни. Це, у свою чергу, веде до слабкого знання населенням законодавства, негативно відбивається на підготовці юридичних кадрів.

Збереження практики хаотичних і частих змін значною мірою нівелює плюси кодифікації, оскільки громадяни, навіть ознайомившись зі змістом кодексу, виданим у поточному місяці, ризикують пропустити зміни в законодавстві, внесені законодавцем після підписання видання до друку.

Помилковою була б відмова від внесення змін у кодифіковане законодавство, яке не може бути закляклим і повинно відповідати потребам сучасного суспільства, яке швидко змінюється. У зв'язку із цим, видається, необхідно знайти компромісне рішення, яке б дозволило водночас підтримувати динамізм кодифікованих законів і забезпечувало їхню стабільність, доконечно необхідну для усвідомлення змісту чинних правових норм права населенням, озброєння юристів, що практикують, якісними екземплярами кодексів, економії матеріальних ресурсів суспільства тощо.

Із цією метою варто запропонувати як обов'язкову умову ухвалення законів, які вносять зміни в кодифікований нормативний правовий акт, положення, згідно з яким усі поправки набувають чинності 1 січня наступного року. Це дозволить представникам юридичної науки і педагогічному складу навчальних закладів юридичного профілю отримати можливість якісно готувати навчальний процес, не боячись, що посеред навчального року несподівано велика кількість наукової та навчальної літератури із предмета курсу, який викладається, безнадійно застаріє, а заміна їй з'явиться через невідомий проміжок часу. 
Виняток із правил, на нашу думку, можна зробити лише для змін у КК України, які стосуються зниження кримінальної відповідальності чи декриміналізації окремих діянь. Такий виняток може бути пояснено тим, що явний пріоритет над зручністю користування законами мають скасування кримінального переслідування або зниження міри покарання.

Розглядаючи юридичну парадигму як гуманітарну систему, можна констатувати, що юридична парадигма, яка нині діє (функціонує), перебуває на етапі кризи компетентності - етапі нездатності повною мірою вирішувати нові правові завдання, що постали перед Україною, по-новому. Немає довіри ні законам, ні законодавцю, ні третій, формально незалежній судовій владі як правозастосувачу, ні правоохоронним органам, одним словом, нікому. Як зазначають фахівці, невіра у право стала нормою, і наші проблеми, пов'язані з удаваністю демократії та неефективністю законодавства, виростають саме 3 невіри у право, невіри, яка становить основу нашого правового нігілізму. А він (правовий нігілізм) притаманний сьогодні не лише пересічним громадянам, але і державним службовцям, законодавцю і більшості юристів-практиків ${ }^{13}$.

Криза, «стряхуючи» систему моделей, які утворюють юридичну парадигму, змушує іiі підсистеми вибудовуватися в новому полі цілісності, допомагає їй (системі) визначити свої найбільш глибокі, найбільш нагальні (пекучі) цінності й інтереси, зокрема щодо гарантування екологічної безпеки.

У реальному житті це проявлясться у виникненні нових, що конкурують із традиційними, типів праворозуміння і правових теорій, нових механізмів правового регулювання, адекватних умовам, які з'явилися, нових ефективних способів розгляду і вирішення (старих невирішених і нових, зумовлених змінами) визначальних завдань екологічної юридичної теорії і юридичної практики, зокрема завдання реального вдосконалення екологічного законодавства i формування правових законів, а також проведення кодифікаційних робіт та інших, спрямованих на гарантування екологічної безпеки.

Аналіз чинного екологічного законодавства і практики його реалізації показує, що зміни, які відбуваються в суспільно-політичному житті України, прямо впливають на «старіння» екологоправових норм, що призводить до їхньої неефективності, а проведення

13 Лаптева Л. Юридическое мировоззрение и законодательство в России. Москва : Юр. лит., 2012. С. 362. 
широкомасштабних реформ спонукає до оновлення практично всіх галузей законодавства, які є складовою частиною комплексної системи законодавства, як екологічне, а також проведення кодифікаційних робіт у зазначеній сфері.

Отже, актуальність дослідження процесів кодифікації екологічного законодавства визначається триваючим процесом кодифікації галузевого законодавства і незавершеністю його теоретичного осмислення.

Зокрема, сьогодні потрібен компроміс між приватноправовими та публічно-правовими інтересами у сфері регулювання екологічних відносин та гарантування екологічної безпеки. Основним джерелом цього має стати особливий характер екологічних прав людини й обов'язку держави їх забезпечити і гарантувати реалізацію, що, у свою чергу, зумовлено потребами громадянського суспільства.

Сповідувана авторами пізнавальна позиція дозволила переосмислити власні підходи, внесені раніше пропозиції, спрямовані на вдосконалення систематизаційних процесів в еколого-правовій сфері, зокрема шляхом кодифікації.

Так, підтримуючи ідею розроблення Екологічного кодексу, доцільно зазначити, що ми сьогодні маємо справу з тим рідкісним випадком, коли не існує освяченої століттями традиції і можна працювати над концепцією кодифікації екологічного законодавства, спираючись лише на суспільну доцільність, європейські цінності та принципи права ${ }^{14}$.

Говорячи про можливість результатів саме кодифікації, хотілося б навести думку українських теоретиків, які вважають, що кодифікаційний акт не тільки впорядковує чинне законодавство, а й якісно його вдосконалює, методологічно «ушляхетнює». Досконалий кодекс сам собою є свідченням високого рівня розвитку юридичної науки та нормотворчості у країні і водночас потужним поштовхом до подальших наукових досліджень відповідної галузі, розроблення та видання нових нормативно-правових актів на виконання його приписів ${ }^{15}$.

Розвиток кодифікаційної діяльності вимагає суворого наукового обгрунтування видів нормативних правових актів, які підлягають використанню, а також чіткого визначення їхнього місця в системі законодавства.

Моделювання на початковому етапі передбачає ідентифікацію основних елементів, з яких надалі буде вибудовуватися основа такої

\footnotetext{
14 Жилінкова І. Правове явище інтернет-відносин. Право Украӥни. 2003. № 5. С. 125.

15 Загальна теорія держави і права: підручник / М. Цвік та ін.; за ред. М. Цвіка, О. Петришина. Харків : Право, 2011. 584 с.
} 
моделі. Що стосується кодифікаційної діяльності в еколого-правовій сфері, тут за основні елементи моделі виступають кодифікаційні нормативні правові акти. Їх сучасне місце в системі екологічного законодавства неоднозначне. Ця обставина утруднює процес моделювання і підлягає усуненню насамперед.

Натепер склалося подвійне становище стосовно юридичної сили результатів кодифікації.

Конституція України не виокремлює в групу кодифіковані нормативні правові акти. Офіційно вони не наділяються більшою юридичною силою, ніж той вид правового матеріалу, який ними систематизований. На практиці норми кодифікованих нормативних правових актів застосовуються з перевагою перед нормами некодифікованих нормативних правових актів аналогічної юридичної сили.

Підмічено, що таке становище призвело до появи в науковому середовищі думки стосовно наявності в кодифікованих нормативних правових актів пріоритету перед іншими нормативними правовими актами тієї ж юридичної сили.

Очевидна двоякість ситуації, яка склалася, з одного боку, кодифіковані нормативні правові акти офіційно не наділяються будь-ким підвищеною юридичною силою і повинні діяти нарівні з іншими нормативними правовими актами того ж рівня та виду. Із другого боку, кодифіковані нормативні правові акти у своїх текстах встановлюють пріоритет закріплених ними правових норм перед правовими нормами, закріпленими іншими нормативними правовими актами стосовно того самого предмета регулювання. І необхідно підкреслити, що такий пріоритет визнається як представниками науки, так і правозастосувачами, а також, що особливо важливо, підтверджується актами обов'язкового тлумачення вищих судових інстанцій.

Таке становище, на нашу думку, не може бути визнане оптимальним із таких підстав. По-перше, будь-яка двоякість нормативних приписів, зокрема тих, які закріплюють колізійні норми, збільшує потенціал збою правового механізму у зв'язку з можливістю неоднозначного тлумачення і застосування правових приписів.

По-друге, виокремленого на практиці поняття пріоритету кодифікованого нормативного правового акта недостатньо для реалізації всіх можливостей кодифікації. Зокрема таких із них, як усунення колізій, що накопичилися в законодавстві. 


\section{ВИСНОВКИ}

Проведений нами аналіз нормативно-правових актів і програмних документів щодо правового регулювання гарантування екологічної безпеки в Україні, а також офіційних позицій органів державної влади щодо стану систематизації екологічного законодавства України дозволяє виокремити такі характерні особливості сучасного систематизаційного процесу в галузі екологічного законодавства України:

1) 3 боку законодавця й органів державної влади не приділяється достатньої уваги питанню систематизації екологічного законодавства України, не дотримуються безперервність та послідовність у даному процесі.

Аналіз стратегічних програмних документів щодо розвитку екологічної політики свідчить, що в них не розглядається систематизація екологічного законодавства України як пріоритетний напрям провадження екологічної політики, як шлях покращення стану навколишнього природного середовища та забезпечення екологічних прав, як один 3 інструментів удосконалення екологічного законодавства;

2) держава «уникає» вирішення проблеми систематизації екологічного законодавства України та взяття відповідальності за громіздкий об'єм роботи.

Окресливши ще в 1998 р. серед основних напрямів державної політики України в галузі охорони довкілля використання природних ресурсів і гарантування екологічної безпеки ${ }^{16}$ систематизацію екологічного законодавства шляхом кодифікації та консолідації, законодавець фактично так і не перейшов до реалізації більшості їхніх складових етапів. У 2003 р. завдання щодо кодифікації екологічного законодавства шляхом розроблення проєкту Екологічного кодексу України Верховна Рада України передоручила Кабінету Міністрів України ${ }^{17}$, який його не виконав. У свою чергу, у 2006 р. Кабінет Міністрів України аналогічно переклав завдання щодо проведення кодифікації екологічного законодавства України у формі Екологічного кодексу України на низку органів виконавчої влади (Мінприроди, Мін'юст, Міністерство надзвичайних ситуацій, Мінекономіки, Держкомзем, Держкомлісгосп,

\footnotetext{
16 Про Основні напрями державної політики України у галузі охорони довкілля, використання природних ресурсів та забезпечення екологічної безпеки : постанова Верховної Ради України від 5 березня 1998 р. Відомості Верховної Ради України. 1998. №o 38-39. Ст. 248.

17 Про рекомендації парламентських слухань щодо дотримання вимог природоохоронного законодавства в Україні : постанова Верховної Ради України від 20 лютого 2003 р. Bidoмості Верховної Ради Украӥни. 2003. № 25. Ст. 182.
} 
Держводгосп, за участю Національної академії наук України), робота яких теж не відобразилася в конкретному результаті;

3) на державному рівні відсутня будь-яка офіційно затверджена концепція систематизації екологічного законодавства.

Сама ідея затвердження такої концепції неодноразово висловлювалася науковцями-правниками. Зокрема, Л. Коморна наголошує на важливості розроблення та затвердження Верховною Радою України Концепції систематизації екологічного законодавства, яка повинна нормативно закріпити форми систематизації екологічної галузі законодавства, їхні параметри, обсяги і строки, стратегічні напрями відповідних систематизаційних робіт, відобразити методологічні підходи щодо критеріїв відбору відповідних нормативних актів, вирішити проблему обсягів законодавчого регулювання екологічних правовідносин тощо, з метою консолідації правотворчих зусиль у цій сфері та виходу на ухвалення обгрунтованих із погляду теорії систематизації законодавства законів ${ }^{18}$.

Водночас Г. Балюк наголошує на важливості проведення систематизації екологічного законодавства України на основі єдиної наукової концепції, основні положення якої полягають у визначенні: цілей і завдань систематизації даної галузі; комплексу вихідних умов систематизації, а також чинників, що впливають на фіксацію умов і меж систематизації екологічного законодавства; форм систематизації стосовно конкретного етапу розвитку екологічного законодавства, їхніх особливостей у зв'язку зі специфікою сучасного стану, тенденцій і проблем розвитку екологічного законодавства; критеріїв відбору систематизуючих нормативно-правових актів щодо обраних форм систематизації; базових правових орієнтирів законодавства, що систематизується (цілей, завдань, принципів, системи дефініційованих правових понять $)^{19}$;

4) питання систематизації екологічного законодавства не $є$ предметом активного обговорення з боку держави на різноманітних слуханнях, круглих столах, конференціях та інших публічних заходах.

Так, ще в 1999 р. Інститутом законодавства Верховної Ради України була проведена масштабна міжнародна науково-практична конференція на тему «Систематизація законодавства в Україні: проблеми теорії

18 Коморна Л. Систематизація екологічного законодавства України: теоретико-правове дослідження : дис. ... канд. юрид. наук: 12.00.01. Київ, 2000. 19 с.

19 Сучасні проблеми систематизації екологічного, земельного та аграрного законодавства України : збірник наукових праць Круглого столу, 18 березня 2011 р. Київ : ВГЛ «Обрії», 2011. $238 \mathrm{c}$. 
і практики» за участю провідних науковців та практиків, де також порушувалося питання систематизації екологічного законодавства України. 3 того часу така активність держави щодо обговорення питання систематизації екологічного законодавства України не була помічена, незважаючи на плідну роботу в даному напрямі юридичної науки. Водночас сьогодні немає фахової дискусії на державному рівні щодо систематизації екологічного законодавства України, наявність якої дозволила б залучити до даного процесу зацікавлену громадськість.

Водночас систематизація екологічного законодавства України є предметом уваги на наукових конференціях і круглих столах наукових і навчальних провідних установ, наприклад, у 2005 р. на базі кафедри трудового, земельного і екологічного права юридичного факультету Київського національного університету ім. Т. Шевченка був проведений Міжнародний круглий стіл під назвою «Екологічний кодекс України: міфи та реальність» ${ }^{20}$, у 2011 р. - Круглий стіл «Сучасні проблеми систематизації екологічного, земельного та аграрного законодавства України ${ }^{21}$;

5) держава в особі органів державної влади стоїть на позиції щодо систематизації екологічного законодавства України шляхом його кодифікації, тобто ухвалення Екологічного кодексу України, без будь-якого обгрунтування вибору саме такої форми систематизації;

6) до процесу систематизації екологічного законодавства України з боку держави фактично не залучена наукова спільнота та майже не беруться до уваги вагомі напрацювання в даній сфері науковців-правників у галузі екологічного права.

Сьогодні широкій увазі зацікавленій цільовій аудиторії представлені серйозні напрацювання представників юридичної науки у сфері систематизації законодавства (дисертаційні дослідження ${ }^{22}$, монографiї ${ }^{23}$, публікації в наукових фахових виданнях тощо). Проблема систематизації безпосередньо екологічного законодавства $€$ предметом уваги чималого числа науковців-правників, які оприлюднили своє бачення на численних конференціях, круглих столах і в наукових статтях.

20 Екологічний кодекс України: міфи та реальність : матеріали Міжнародного круглого столу, 12-13 травня 2005 р. Київ : Видавничо-поліграфічний центр «Київський университет», 2005. $115 \mathrm{c}$.

21 Сучасні проблеми систематизації екологічного, земельного та аграрного законодавства України : збірник наукових праць Круглого столу, 18 березня 2011 р. Київ : ВГЛ «Обрії», 2011. 238 c.

22 Меленко С. Консолідація як вид систематизації нормативно-правових актів : автореф. дис. ... канд. юрид. наук: 12.00.01. Київ, 2002. 19 с.

23 Систематизація законодавства України: проблеми та перспективи вдосконалення : монографія. Київ : Інститут держави і права ім. В.М. Корецького НАН України, 2003. 220 с. 
Однак прикро відзначати, що до діючого процесу систематизації екологічного законодавства України з боку органів державної влади фактично не залучається наукова громадськість, представники галузі екологічного права та його суміжних наук, даний процес не координується і не узгоджується 3 науковим осередком, а вагомі досягнення в даній сфері науковців-правників залишаються поза увагою.

Отже, проведений аналіз стану систематизаційного процесу в Україні в галузі екологічного законодавства України свідчить, що, на жаль, натепер Україна не може похвалитися успіхами в цій сфері. Будь-якого істотного прогресу в напрямі систематизації екологічного законодавства не спостерігається, а поодинокі ініціативи органів державної влади щодо системного вдосконалення екологічного законодавства не увінчуються жодним результатом. Водночас невирішення проблеми систематизації екологічного законодавства України не знімає це питання з порядку денного, а лише посилює його актуальність, адже кількість нормативно-правових актів у сфері охорони навколишнього природного середовища, гарантування екологічної безпеки та використання природних ресурсів лише зростає, наявні між ними суперечності та неузгодженості, інші недоліки не зникають, що негативно позначається на стані навколишнього природного середовища, забезпеченні екологічних прав, правовому регулюванні екологічних відносин та правозастосовній діяльності.

\section{АНОТАЦІЯ}

У статті проведено аналіз сучасного стану нормативно-правового регулювання гарантування екологічної безпеки України та виявлено його прогалини. Проведено класифікацію нормативно-правових актів у сфері гарантування екологічної безпеки України залежно від їхнього змісту. Внесено пропозиції щодо систематизації законодавства України у сфері гарантування екологічної безпеки. Так, зокрема, авторами підтримано висловлену у спеціальній літературі пропозицію щодо розроблення й ухвалення Екологічного кодексу України. Обгрунтовано необхідність синхронної систематизації ядерного законодавства шляхом розроблення й ухвалення Ядерного кодексу України, енергетичного законодавства шляхом розроблення й ухвалення Енергетичного кодексу України, містобудівного законодавства шляхом ухвалення Містобудівного кодексу України з метою забезпечення ефективності правового регулювання в зазначених сферах і гарантування конституційного права людини на безпечне для життя та здоров'я довкілля. 


\section{ЛІТЕРАТУРА}

1. Данилов-Данильян В., Лосев К. Экологические вызовы и устойчивое развитие. Москва, 2000. С. 407.

2. Декларація про державний суверенітет України від 16 липня 1990 р. Відомості Верховної Ради Української Радянської Сосиіалістичної Республіки. 1990. № 31. Ст. 429.

3. Екологічний кодекс України: міфи та реальність: матеріали Міжнародного круглого столу, 12-13 травня 2005 р. Київ : Видавничополіграфічний центр «Київський університет», 2005. 115 с.

4. Жилінкова I. Правове явище інтернет-відносин. Право Украӥни. 2003. № 5. C. 125.

5. Загальна теорія держави і права : підручник / М. Цвік та ін. ; за ред. М. Цвіка, О. Петришина. Харків : Право, 2011. 584 с.

6. Коморна Л. Систематизація екологічного законодавства України: теоретико-правове дослідження : дис. .... канд. юрид. наук: 12.00.01. Київ, 2000. 19 c.

7. Конституція України від 28 червня 1996 р. Відомості Верховної Ради Украӥни. 1996. № 30. Ст. 141.

8. Лаптева Л. Юридическое мировоззрение и законодательство в России. Москва : Юр. лит., 2012. С. 362.

9. Меленко С. Консолідація як вид систематизації нормативноправових актів : автореф. дис. ... канд. юрид. наук: 12.00.01. Київ, 2002. $19 \mathrm{c}$.

10. МунтянВ.Правовыепроблемырациональногоприродопользования : автореф. дис. ... докт. юрид. наук. Киев, 1975. С. 7.

11. Надоша О. Теоретико-методологічний аналіз сталого розвитку в контексті сучасних дослідницьких підходів. Державне управління: удосконалення і розвиток. 2011. № 10. С. 17.

12. Про внесення змін до Кримінального та Кримінального процесуального кодексів України щодо виконання рекомендацій, що містяться у шостій доповіді Європейської комісії про стан виконання Україною Плану щодо лібералізації Європейським Союзом візового режиму для України, стосовно удосконалення процедури арешту майна та спеціальної конфіскації : Закон України від 18 лютого 2016 р. Відомості Верховної Ради України. 2016. № 11. Ст. 127.

13. Про національну безпеку України : Закон України від 21 червня 2018 р. Відомості Верховної Ради Украӥни. 2018. № 31. Ст. 241.

14. Про Основні напрями державної політики України у галузі охорони довкілля, використання природних ресурсів та забезпечення екологічної безпеки: постанова Верховної Ради України від 5 березня 1998 р. Відомості Верховної Ради Украӥни. 1998. №№ 38-39. Ст. 248. 
15. Про охорону навколишнього природного середовища: Закон України від 25 червня 1991. Відомості Верховної Ради України. 1991. № 41. Ст. 546.

16. Про рекомендації Парламентських слухань щодо дотримання вимог екологічного законодавства в Україні, напрямів реалізації і вдосконалення екологічної політики : постанова Верховної Ради України від 7 грудня 2000 p. URL: https://zakon.rada.gov.ua/laws/show/2130-14.

17. Про рекомендації парламентських слухань щодо дотримання вимог природоохоронного законодавства в Україні : постанова Верховної Ради України від 20 лютого2003 р. Відомості Верховної Ради Украӥни. 2003. № 25. Ст. 182.

18. Систематизація законодавства України: проблеми та перспективи вдосконалення : монографія. Київ: Інститут держави i права ім. В.М. Корецького НАН України, 2003. 220 с.

19. Сучасні проблеми систематизації екологічного, земельного та аграрного законодавства України : збірник наукових праць Круглого столу, 18 березня 2011 р. Київ : ВГЛ «Обрії», 2011. 238 с.

20. Шемшученко Ю. Виміри порівняльного правознавства. Право України. 2013. №№ 3-4. С. 15-21.

\section{Information about the authors:}

Balyuk G. I., orcid.org/0000-0001-5855-0142

Ph. D. (Law), Corresponding Member of the National Academy of Legal Sciences of Ukraine,

Professor of Ecological Department Taras Shevchenko National University of Kyiv 60, Volodymyrska str., Kyiv, 01033, Ukraine

Kovalchuk T. G., orcid.org/0000-0003-0157-2767 Ph. D. (Law), Associate Professor, Head of Ecological Law Department

Taras Shevchenko National University of Kyiv 60, Volodymyrska str., Kyiv, 01033, Ukraine

DOI https://doi.org/10.30525/978-9934-588-43-3/1.17 